\title{
Apresentação
}

\section{Literatura e Democracia}

Não está fácil falar em democracia. Não é fácil falar em democracia. O primeiro enunciado indica um problema contemporâneo. O segundo, um problema conceitual. Grosso modo, fica indicada uma tensão entre a sincronia e a diacronia, ou, em outras palavras, entre a vivência de uma ideia, sua atualização, sua aplicação, e a própria possibilidade de pensá-la. Hoje em dia, temos assistido ao recrudescimento de ameaças reais à democracia enquanto garantia de equilíbrio entre igualdade e desigualdades nas (insuperáveis?) oligarquias em que vivemos. É como se o espírito democrático começasse a deixar de ser significativo mesmo enquanto escudo retórico - não era em nome da democracia que os Estados Unidos lideravam campanhas de derrubada de governos, desde o soviético e seus satélites até o iraquiano de Sadam? Ou, pelo contrário, a democracia tornou-se um mero recurso de retórica, sem força sequer para mover-se como potente enunciado teórico? Fato é que, hoje em dia, assusta muita gente a democracia já começar a perecer em muitas falas, sendo substituída por outras urgências sociais - a segurança, a exclusão oficializada, o aumento descomunal do tamanho dos muros.

Perante a fragilidade da palavra "democracia" reivindicada, perseguida, esvaziada -, que responsabilidades tem a escrita literária? A Revolução Francesa é impensável sem os escritores iluministas e pré-românticos; o sentido da liberté, da égalité, da fraternité é experimentado em novelas e romances de Voltaire, Diderot, Rousseau, ao mesmo tempo que alcança as ruas - e as prisões. A modernidade política faz-se também nos textos literários. Por outro lado, a poesia de Eliot, Pound, Pessoa opõe aos modelos democráticos narrativas aristocráticas, conservadoras, se não fascistas: os modernismos negam as modernidades, e a escrita é o local de uma recusa, de um reduto, torre de marfim bem acima da polis. Mário de Sá-Carneiro lamenta-se, no início de "Manucure": eis-nos chegados a um "dia brutal, provinciano e democrático 
/ Que os meus olhos delicados, refinados, esguios e citadinos / Nem podem tolerar - e apenas forçados / Suportam em náuseas". Por outro lado, é o mesmo Pessoa quem escreverá, já no fim da vida, contra a ditadura de Salazar, e o século XX português, de Sophia de Mello Breyner Andresen a Ruy Belo, passando por todo o Neorrealismo, discute com força o lugar da democracia nos textos.

Já no Brasil, o Modernismo que se pretendeu libertar de um paradigma colonizante até na fala não deixou de contribuir para uma literatura sempre atenta ao político, que tem no Drummond d'A rosa do povo um exemplo portentoso. Espaço de ditaduras específicas e de uma vocação ditatorial (escravocrata, com certeza) de difícil dissolução, o Brasil, como boa parte do continente latino-americano, demanda da sua arte uma atuação por vezes direta em termos de combate democrático.

Seja em que língua for, hoje em dia enxergamos experimentos que trabalham a democracia também como procura de uma linguagem, de linguagens - o próprio fato de se poder escrever, a favor da democracia ou mesmo contra ela, não será já um sinal de vivência democrática? Mais que isto, escreve-se, hoje em dia, na vigência de um capitalismo sufocante, que corre pouquíssimos riscos mesmo dentro dos estados de exceção que se anunciam mundo afora; neste contexto, não estará a forma artística vocacionada a procurar a proposição de novas estéticas emancipatórias?

Este número da Gragoatá passeia pela democracia em literatura em várias línguas, diferentes momentos históricos e diversos gêneros, do ensaio à epístola, da poesia à narrativa (ainda que, não obstante a presença de várias ensaístas mulheres, entendamos a escassez de autoras em estudo como uma democracia em estado de vinda). Não surpreende a atenção dada à literatura contemporânea, sendo o nosso tempo palco de algumas das inquietações mais evidentes neste universo. A indicar, por outro lado, que a democracia é um problema antigo, tão antigo como nossa obsessão por pensar enquanto escrevemos, lemos e ouvimos, outros tempos aparecem nestes artigos, do século XVI ao começo do XX, passando pelo incontornável XIX, lugar de partida do que entendemos, hoje, como moderno.

Democracia, problema antigo, de que não é fácil falar. Jacques Rancière, um dos autores estudados neste número, 
lembra-nos de que, na origem da democracia, há a participação decisiva do acaso. $\mathrm{O}$ mesmo acaso, por vezes atendendo por outros nomes, também participa da arte, seja no espaço da recepção, seja no da desconstrução de hierarquias diversas, gesto que não deixa de ser, por si só, democrático.

Luis Maffei

Pedro Eiras

Organizadores 